\title{
Book Reviews - Buchbesprechungen - Livres Nouveaux
}

Dermatologie und Venerologie, einschließlich Berufskrankheiten, dermatologischer Kosmetik und Andrologie. Hgb. von: H. A. Gottron und W. Schönfeld. Band I/Teil 2, Thieme, Stuttgart 1962. XII, 719 S., 284 Abb., DM 188.-, Subskriptions-preis DM 146.40.

Dieser neue Band des Handbuches der Dermatologie und Venerologie behandelt die «Allgerneine klinische Dermatologie» (W. Schönfeld) in einem erschöpfenden Bei-trag (84 S.), der eine ausgezeichnete Einleitung zum Studium der Hautkrankheiten bietet. Die Diagnostik der Hautkrankheiten ist vielleicht in höherem Maße als die auf anderen Gebieten der Klinik auf die direkte Beobachtung der Krankheitserscheinungen gegründet. Untersuchungen im Laboratorium haben dann ihren großen Wert als Be-kräftigung der klinischen Diagnose und Wegleitung zu einer rationellen Therapie. Die systematische und klare Darstellung von Schönfeld, die auch sehr gut illustriert ist, ist daher von großer Bedeutung. Anschließend werden folgende Gebiete behandelt: «Statistik in ihrer Bedeutung für die Dermatologie» (H. J. Heite), «Ethnographische Dermatologie» (R. Richter), «Wetter-Klima-Haut» (K. Daubert) und «lnstrumen-tenlehre» (G. Riedel). W. Schneider und H. Ruther tragen mit einem inhaltsreichen Kapitel über «Allgerneine Therapie» bei. Dieses Kapitel zeigt, daß die Behandlung der Hautkrankheiten oft rein empirisch geschieht und daß auf diesem Gebiet intensive For-schung notwendig ist. W. Schneider und Mitarb. behandeln auch die praktisch be-deutungsvollen Probleme der Reinigung und Pflege der Haut und geben eine gute An-leitung zur Pruning von Hautwasch- und Pflegemitteln. S. Bommer bespricht die Er-gebnisse der Ernährungstherapie, J. Vonkennel und M. Schoog stellen die Chemo-therapie und die Anwendung von Antibiotika in der Dermatologie dar. J. Kimmig und R. Wehrmann geben eine kurze (61 S.) Darstellung der «Biochemie der Haut». Man hätte gewünscht, daß dieses Gebiet eine viel ausführlichere Darstellung erfährt. Das umfangreiche Literaturverzeichnis dürfte aber das weitere Studium erleichtern. W. Schönfeld hat die Syndrome und Krankheitsbilder in der Dermatologie, die mit Perso-nennamen bezeichnet werden, zusammengestellt. Es ist zu hoffen, daß diese Bezeich-nungen allmählich einer rationellen Nomenklatur Platz geben werden. Die zwei ab-schließenden Darstellungen behandeln «Die Zeugungsfähigkeit des Mannes und ihre Störungen» (W. Nikolowski) und die «TrichomonadenInfektion» (H. Bauer) .

Paul Kallós, Helsingborg

Crowle, A. J.: Immunodiffusion. Academic Press, New York/London 1961. X+334 pag., illustr., \$10.00.

During the last years immunological research has demonstrated the great usefulness of the immunodiffusion techniques. These methods have been applied to a large number of problems in various fields and several technical modifications have been published. There has been an obvious need for a handbook which comprises all the available information to date on the immunodiffusion techniques and their applications. Such a monograph has been presented by Alfred J. Crowle in his book "Immunodiffusion" which is dedicated to J. Oudin, Ö. Ouchterlony, S. D. Elek and P. Gra-bar, "the pioneers in the perfection and popularization of semisolid medium serologic techniques". 
The monograph is introduced by a historical review which presents the intereseting background to the development of these new techniques which have formed the basis for the progress of modern immunology. The history of immunodiffusion is, accordingly to the author, divisible into "a period of blind infancy before 1946 and a period of

Book Reviews - Buchbesprechungen - Livres Nouveaux 311

phenomenal maturation in following years". The first period is represented by a few reports employing semi-solid media for the study of organic material, by examination of antigenantibody reactions. The "second period" in which the remarkable development of immunodiffusion techniques took place, was initiated by Oudin, Ouchterlony and Elek who established the facts that each precipitation line represented a separate antigen-antibody system and that these methods could be used for comparative studies of antigenic material as well as of antibodies. A further important step was taken by the introduction of the immunoelectrophoretic method by Grabar and Williams.

The author introduces the basic facts about immunoprecipitation and diffusion and presents the dynamics of the three principle techniques, single diffusion, double diffusion and immunoelectrophoresis.

The literature describing various applications of the immunodiffusion methods is so vast that it is almost impossible to compass everything in a survey of this kind, but the author presents a very extensive and readily understood review of the various fields in which important contributions have been made by diffusion-in-gel techniques.

Detailed information about various techniques and modifications thereof is also collected in the monograph. Several valuable technical aspects are presented and critically discussed making the survey a useful handbook for the novice as well as for the more experienced investigator.

A comprehensive list of references up to the middle of 1960 has been compiled. In the glossary the author shows his preference for the expressions: pattern of fusion, pattern of intersection, and of partial intersection, instead of the older, criticized terms: reaction of identity, of non-identity and of partial identity. These parallel the terms: reaction of interference of non-interference and of partial interference more recently suggested by Ouchterlony.

The monograph is enhanced by appendices containing formulae for suitable immunoelectrophoretic buffers, protein stains etc.

Lars Å. Hanson, Göteborg

Progress in Drug Research, Ed. by E. Jucker. Vol. II, Birkhäuser, Basel 1960. 636 pp., sFr. 85 .-. Progress in pharmacological work at the present time is so rapid that it is a delight to read recent reviews written by specialists in their respective fields. The aim of the Editor of this Progress Series is to present coverage of the more important lines of drug research so that the full series may become a work of reference. In the present Volume II, nine articles are brought together and various topical subjects of pharmacological research have been surveyed.

In the first chapter, development of the newer diuretic drugs has been traced in some 60 pages by K. H. Beyer and J. E. Baer (of Merck Institute in the U.S.A.). These authors are well-known for their work in this field, particularly with chloro-thiazide and its related compounds, and it is a pleasure to read their exhaustive chapter. They suggest that future studies of the interaction of various classes of diuretic agents may provide even better clinical agents than at present but I think more stress should be directed in articles of this type to adequate controls being used in these studies. From Milan, a chapter on anabolic steroids is dealt with by B. Camerino and G. Sala. It is written in English but after reading the 60 pages one is still left with an open mind 
about the full clinical value of these compounds. Anabolic steroids should be compounds which cause nitrogen retention but how often is this needed.

The next chapter by C. J. Cavallito and A. P. Gray (from U.S.A.) describes the chemical nature and some pharmacological actions of quaternary ammonium salts. The reading is hard-going but it is well worth it. I was disappointed to find few com-

312 Book Reviews - Buchbesprechungen - Livres Nouveaux

ments about future advances in this field. In a short and concise chapter, A. Cerletti (Sandoz, Basel) summarizes very clearly the existing state of knowledge in the field of indoles. Much research has been put into this topic in recent times and the indole structure is of great importance in medicine and biology. Then there is a remarkable chapter of 40 pages by $\mathrm{W}$. Kunz (of Düsseldorf) on the most important pharmaceutical preparations introduced in the past few years. It is in German but there is world-wide coverage of medicaments. Again there is no personal comment about future progress.

The next chapter contains over 100 pages on ganglion blocking drugs by K. Nádor (Hungary). To some extent, this overlaps with the account of quaternary ammonium salts but greater detail is given (by way of extensive tables) to those series of compounds which have potential clinical application. There follows an exhaustive chapter on the chemistry, biochemistry, pharmacology and clinical uses of mono-amine oxidase inhibitors by A. Pletscher, K. F. Gey and P. Zeller (from Hoffmann-La Roche, Basel). This is composed of over 150 pages with no fewer than 1389 references. The exceedingly fast development of this research topic makes it difficult to keep up with the latest advances, and this chapter (written in German) will remain an encyclopedia for some time to come. The final two chapters are short. A. W. Sexton (of I.C.I., England) writes on the structure and biogenesis of antibiotics derived from acetic acid and from amino-acids, and D. W. Woolley (of. U.S.A.) discusses antimetabolites and their "revolution" in pharmacology. Although brief, they are stimulating to the reader.

In conclusion, it may be said that the second colume of this Series gives a good survey of various topical subjects of pharmaceutical research and can be thoroughly recommended to the active researcher. The volume is well-produced on good paper and should be on every library shelf.

G. B. West, London

E. Bernard et B. Gamain: Bronchographíe clinique. Masson, Paris 1961. 196 p., 132 fig., 29 schémas, NF 52.-.

La bronchographie qui au debut de son application était surtout utilisée pour préciser le diagnostic de dilatation des bronches connait depuis quelques dix ans une relance grace aux progrès de sa realisation technique, à la chirurgie d'exérèse qui exige un bilan minutieux des lesions et aux approches diagnostiques qui dans maintes affections bronchiques pulmonaires se veulent de plus en plus precises.

Après une etude des produits de contraste et de la technique proprement dite avec ses incidents et accidents, les auteurs nous font un expose détaillé, grace à une très belle et importante iconographie, des renseignements fournis par la bronchographie, ces renseignements étant d'ordre anatomique ou d'ordre fonctionnel.

Le chapitre suivant concerne les indications de la bronchographie.

La connaissance parfaite de Pimage bronchographique normale étant une condition indispensable au dépistage des anomalies ou alterations, un important chapitre est consacré à $\Gamma$ arbre bronchique normal ainsi qu'aux malformations, aux remaniements spontanés et aux modifications après exérèse. 
Toutes les affections ou un bronchogramme est utile sont passées en revue mais ce qui intéressera surtout $\Gamma$ allergiste c'est le diagnostic bronchographique des bronchor-rhées et des syndromes pseudo-bronchectasiques qui sont souvent des equivalents asthmatiques.

R. Panzani, Marseille 